\title{
Mikania Cordata (Burm.F.) B.L. Rob. - A Bangladesh Folk Medicinal Plant for Gastric Disorders
}

\author{
Sourav Paul ${ }^{1}$, Md Shakil Ahammed ${ }^{1}$, Be-nazir Farzana ${ }^{1}$, Rownak Jahan ${ }^{1}$, Majeedul H Chowdhury ${ }^{2}$ and \\ Mohammed Rahmatullah ${ }^{1 *}$ \\ ${ }^{1}$ Department of Biotechnology \& Genetic Engineering, University of Development Alternative, Bangladesh \\ ${ }^{2}$ Department of Biology, Touro College \& University System, Flatbush Campus, USA
}

*Corresponding author: Mohammed Rahmatullah Dean, Faculty of Life Sciences, University of Development Alternative, Lalmatia, Dhaka-1207, Bangladesh.
Received Date: September 13, 2019

Published Date: September 18, 2019

\begin{abstract}
Mikania cordata (Burm.f.) B.L. Robinson belongs to the Asteraceae family of plants and is a rapidly growing creeping perennial vine found in Bangladesh and other tropical regions. In Bangladesh, the plant is known by a number of names like 'refugee lota', 'libuji lota', 'assam lota', and 'gastric gach', the latter meaning gastric plant. In English, the plant is known as bitter vine, climbing hemp vine, and American rope. The plant is considered an important folk medicinal plant in Bangladesh and is used in the north central districts of Bangladesh (like Jamalpur) for treatment of gastric disorders. Other medicinal uses of the plant in Jamalpur district, Bangladesh include use as poultice for treatment of swelling, itches and wounds. This paper attempts to correlate the folk medicinal uses of the plant in Bangladesh versus ethnic uses reported from other countries along with reported relevant phytochemicals and pharmacological activities.
\end{abstract}

Keywords: Folk medicine; Mikania cordata; Ethnic uses; Jamalpur; Bangladesh

\section{Introduction}

Plants produce a bewildering variety of phytochemicals, otherwise known as secondary metabolites. Secondary metabolites are compounds, which are not necessary for a plant cell to live but are necessary for a plant to survive biotic or abiotic stresses [1]. Secondary metabolites can produce pharmacological responses when introduced into humans, which in turn can be toxic or serve therapeutic purposes. A number of such secondary metabolites have been isolated and have found uses in medicine like aconitine, L-hyoscyamine, camptothecin, tetrahydrocannabinol, and tubocurarine, to name only a few [2]. Although the existence of secondary metabolites were possibly not known or understood by ancient hominids, plants have always played a role in the treatment of diseases from the beginning of humankind. Medicinal plant material has been found in a 60, 000 year old Neanderthal grave in Iraq [3]. Early Asian and Egyptian texts (since the discovery of writing and writing materials) mention medicinal plants and their uses [4]. Use of plants as medicines since time immemorial gradually led to the establishment of distinct forms of traditional medicinal practices like the Ayurveda in India, Unani in Greece, Kampo in Japan, and other systems throughout the world [5]. Besides these 'ritualized' forms of traditional medicinal systems, there also exists folk medicine (FM), tribal medicine (TM, same as FM but practiced by tribal people instead of the mainstream population), and home remedies. Allopathic medicine has borrowed heavily from traditional medicinal practices and more than a hundred allopathic drugs are plant-derived [6]. It has been said that approximately 70 $80 \%$ of primary health care throughout the world is based on plant materials [7].

To discover a new allopathic drug starting from traditional medicinal practices, an excellent place to start is folk medicine or ethnomedicinal reports on any given plant. The more the number of reports and agreement on the plant's medicinal use in those reports, the better probability is that a new drug can be discovered from the plant. So the first thing to do is perform an ethnobotanical survey and compare it with other ethnobotanical surveys. During the past ten years, we had been doing ethnobotanical surveys in 
Bangladesh in an extensive manner [8-37], for ethnobotany is still at its infancy in this country. On the other hand, the country has a rich floral diversity with around 5500 floral species. So the probability of new drug discovery is higher in countries like Bangladesh with a rich diversity of flora, which remains to be scientifically studied, but which plants have been medicinally used from time immemorial but the data lies scattered among the folk medicinal practitioners (FMPs) or other types of traditional medicinal practitioners. So the primary objective of any scientist dealing with drug discovery from natural products is to analyze the ethnobotanical data from different angles. Mikania cordata (Burm.f.) B.L. Robinson is a vinous perennial plant found in tropical regions like Bangladesh and belongs to the Asteraceae family. In Bangladesh, the plant is known by a number of names like 'refugee lota', 'libuji lota', 'assam lota', and 'gastric gach', the latter meaning gastric plant. In English, the plant is known as bitter vine, climbing hemp vine, and American rope. The plant is considered an important medicinal plant in Bangladesh. It was our objective to compare the ethnic uses of the plant and check out the scientific validation of some uses. The plant was chosen because one of its local names is 'gastric gach', suggesting that the plant may have a long history of folk medicinal use for alleviating gastric disorders.

\section{Methods}

Preliminary information was obtained from a FMP practicing in Ramnagar village in Jamalpur district, Bangladesh. Prior informed consent was initially obtained from the FMP. The FMP was informed the reason for our visit and consent obtained to disseminate any information provided both nationally and internationally. Actual interviews were conducted in the Bengali language, which was spoken fluently by the FMP as well as the interviewers, the language being the mother tongue of FMP, villagers and the interviewers. The FMP mentioned the name 'gastric gach' and described its various uses. He also took the interviewers to show a sample of the plant. The plant was photographed and plant specimen brought to Dhaka for identification by a competent botanist at the University of Development Alternative (UODA). A voucher specimen was deposited at the Medicinal Plant Collection Wing of UODA. Secondary information on the ethnobotany, pharmacological properties and phytochemicals of the plant used by the FMP were obtained from papers in PubMed, SCOPUS and Google Scholar abstracted journals.

\section{Results and Discussion}

The plant shown by the FMP was identified as Mikania cordata (Figure 1). The FMP used the leaves of the plant to treat primarily gastric symptoms. Other uses by him were for treatment of swelling, itches and wounds, where the plant was used as a poultice. However, for gastric disorders, aqueous extract of leaves (one spoon) was taken orally in the morning on an empty stomach. This was done till gastric disorder was cured. By gastric disorder the FMP meant acidity, stomach pain, bloating, bleeding with stool and heartburn, all of them being possible symptoms of gastric ulcer. In Barisal district (located in the southern part of Bangladesh), the leaves of the plant are used to treat wounds and gastric disorders [38]. In Shitol Para village of Jhalokati district, Bangladesh, the leaves are used to stop bleeding [39]. The leaves of the plant are used by the Ilongot-Egongot community of Bayanihan, Maria Aurora, Aurora, Philippines, for treatment of toothache [40]. The Tonchongya tribe of Bandarban district, Bangladesh, uses leaves of the plant to stop bleeding from cuts and wounds [41]. The Sundanese people at the Bodogol area, Gede Pangrango Mountain National Park, West Java, Indonesia, use the plant to treat coughs [42]. Leaves are used as antiseptic on wounds and to stop bleeding by tribal people residing in South and West district of Tripura State, India [43]. Leaves of the plant are used to stop bleeding from cuts and wounds by various communities residing in Garo Hills of Durgapur, Bangladesh [44]. The people residing in Surigao Del Sur Mountain Region, Philippines use the plant for genitor-urinary disorders [45]. A Tonchongya tribal healer in Cox's Bazar district, Bangladesh reportedly used leaves of the plant to treat cuts and wounds to stop bleeding and to treat piles, indigestion, diarrhea, and gonorrhea [46]. The Meetei healers of Manipur, India use leaves of the plant to treat snake bites [47]. The FMPs residing around the Rema-Kalenga Wildlife Sanctuary, Habiganj district, Bangladesh use leaves of the plant to stop bleeding from cuts and wounds [48]. The Chorei tribe of Southern Assam, North Eastern India uses the leaves of the plant to treat cuts and wounds [49]. The leaves of this plant are used by inhabitants of Batak Simalungun, North Sumatra, Indonesia, to cure gastrointestinal disorders. The plant has a bitter taste caused by the presence of tannins in the plant, which compounds can form a thin layer on the lumen thus reducing irritation [50] (Figure 1).

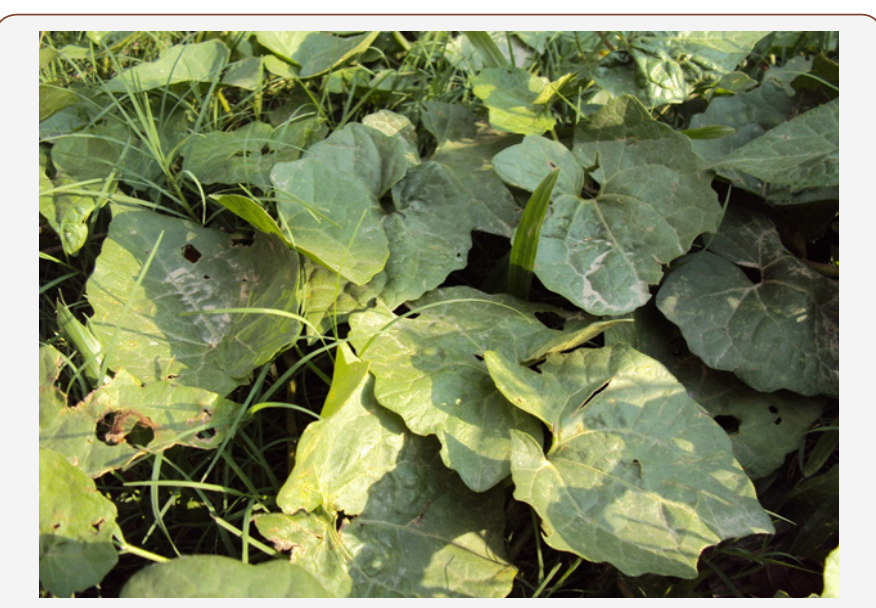

Figure 1: Mikania cordata.

From ethnobotanical reports, it appears that the most common ethnic use of the plant is to stop bleeding from cuts and wounds. However, a recent review has pointed out that Mikania genus plants such as M. glomerata, M. laevigata and M. cordata are active against disorders of the digestive system including inhibition of gastric ulcers [51]. Sesquiterpene compounds are abundant in Mikania genus plants [51] and sesquiterpenes like alpha-cubebene, caryophyllene oxide, alpha-bisabolol, gamma-curcumene, betapinene, copaene, alpha-cedrene, and spathulenol are present in 
Mikania cordata [52]. The anti-ulcer activity of sesquiterpenes has been reported [53].

\section{Conclusion}

Leaves of Mikania cordata are used by a FMP of Jamalpur district, Bangladesh for treatment of gastric symptoms. Isolated ethnobotanical reports also demonstrate the use of the leaves of the plant against gastric disorders though most reports indicate ethnic use against cuts and wounds. Perusal of various scientific reports suggests that the plant is rich in tannins and sesquiterpenes, which compounds are beneficial in gastrointestinal tract disorders like diarrhea and gastric ulcer.

\section{Acknowledgement}

The authors are grateful to the FMP for providing information on the plant.

\section{Conflict of Interest}

The authors declare that there are no conflicts of interest.

\section{References}

1. Pagare S, Bhatia M, Tripathy N, Sonal P, Bansal YK (2015) Secondary metabolites of plants and their role: Overview. Curr Trends Biotechnol Pharm 9(3): 294-305.

2. Wink M (2015) Modes of actions of herbal medicines and plant secondary metabolites. Medicines 2(3): 251-286.

3. Lietava J (1992) Medicinal plants in a Middle Paleoloithic grave Shanidar IV? J Ethnopharmacol 35(3): 263-266.

4. Yang SZ (2007) The Divine Farmer's Materia Medica: a translation of the Shen Nong Ben Cao Jing. Blue Poppy Press, Colorado, USA.

5. Shankar K, Liao LP (2004) Traditional systems of medicine. Physical Medicine and Rehabilitation Clinics of North America 15(4): 725-747.

6. Fabricant DS, Farnsworth NR (2001) The value of plants used in traditional medicine for drug discovery. Environ Health Perspect 109(1): 69-75.

7. Mamedov NA, Craker LE (2012) Man and medicinal plants: a short review. Acta Hort 964(961): 181-190.

8. Rahmatullah M, Ferdausi D, Mollik MAH, Jahan R, Chowdhury MH, et al. (2010) A Survey of Medicinal Plants used by Kavirajes of Chalna area, Khulna District, Bangladesh. Afr J Tradit Complement Alternat Med 7(2): 91-97.

9. Rahmatullah M, Khatun MA, Morshed N, Neogi PK, Khan SUA, et al. (2010) A randomized survey of medicinal plants used by folk medicinal healers of Sylhet Division, Bangladesh. Adv Nat Appl Sci 4(1): 52-62.

10. Rahmatullah M, Kabir AABT, Rahman MM, Hossan MS, Khatun Z, et al. (2010) Ethnomedicinal practices among a minority group of Christians residing in Mirzapur village of Dinajpur District, Bangladesh. Adv Nat Appl Sci 4(1): 45-51.

11. Rahmatullah M, Momen MA, Rahman MM, Nasrin D, Hossain MS, et al. (2010) A randomized survey of medicinal plants used by folk medicinal practitioners in Daudkandi sub-district of Comilla district, Bangladesh. Adv Nat Appl Sci 4(2): 99-104.

12. Rahmatullah M, Mollik MAH, Ahmed MN, Bhuiyan MZA, Hossain MM, et al. (2010) A survey of medicinal plants used by folk medicinal practitioners in two villages of Tangail district, Bangladesh. Am-Eur J Sustain Agric 4(3): 357-362.

13. Rahmatullah M, Mollik MAH, Islam MK, Islam MR, Jahan FI, et al. (2010) A survey of medicinal and functional food plants used by the folk medicinal practitioners of three villages in Sreepur Upazilla, Magura district, Bangladesh. Am-Eur J Sustain Agric 4(3): 363-373
14. Rahmatullah M, Jahan R, Khatun MA, Jahan FI, Azad AK, et al. (2010) A pharmacological evaluation of medicinal plants used by folk medicinal practitioners of Station Purbo Para Village of Jamalpur Sadar Upazila in Jamalpur district, Bangladesh. Am-Eur J Sustain Agric 4(2): 170-195.

15. Rahmatullah M, Ishika T, Rahman M, Swarna A, Khan T, et al. (2011) Plants prescribed for both preventive and therapeutic purposes by the traditional healers of the Bede community residing by the Turag River, Dhaka district. Am-Eur J Sustain Agric 5(3): 325-331.

16. Rahmatullah M, Azam MNK, Rahman MM, Seraj S, Mahal MJ, et al. (2011) A survey of medicinal plants used by Garo and non-Garo traditional medicinal practitioners in two villages of Tangail district, Bangladesh. Am-Eur J Sustain Agric 5(3): 350-357.

17. Rahmatullah M, Biswas KR (2012) Traditional medicinal practices of a Sardar healer of the Sardar (Dhangor) community of Bangladesh. J Altern Complement Med 18(1): 10-19.

18. Rahmatullah M, Hasan A, Parvin W, Moniruzzaman M, Khatun A, et al. (2012) Medicinal plants and formulations used by the Soren clan of the Santal tribe in Rajshahi district, Bangladesh for treatment of various ailments. Afr J Tradit Complement Alternat Med 9(3): 350-359.

19. Rahmatullah M, Khatun Z, Hasan A, Parvin W, Moniruzzaman M, et al. (2012) Survey and scientific evaluation of medicinal plants used by the Pahan and Teli tribal communities of Natore district, Bangladesh. Afr J Tradit Complement Alternat Med 9(3): 366-373.

20. Rahmatullah M, Azam MNK, Khatun Z, Seraj S, Islam F, et al. (2012) Medicinal plants used for treatment of diabetes by the Marakh sect of the Garo tribe living in Mymensingh district, Bangladesh. Afr J Tradit Complement Alternat Med 9(3): 380-385.

21. Rahmatullah M, Khatun Z, Barua D, Alam MU, Jahan S, et al. (2013) Medicinal plants used by traditional practitioners of the Kole and Rai tribes of Bangladesh. J Altern Complement Med 19(6): 483-491.

22. Rahmatullah M, Pk SR, Al-Imran M, Jahan R (2013) The Khasia tribe of Sylhet district, Bangladesh, and their fast-disappearing knowledge of medicinal plants. J Altern Complement Med 19(7): 599-606.

23. Akter S, Nipu AH, Chyti HN, Das PR, Islam MT, et al. (2014) Ethnomedicinal plants of the Shing tribe of Moulvibazar district, Bangladesh. World J Pharm Pharmaceut Sci 3(10): 1529-1537.

24. Azad AK, Mahmud MR, Parvin A, Chakrabortty A, Akter F, et al. (2014) Medicinal plants of a Santal tribal healer in Dinajpur district, Bangladesh. World J Pharm Pharmaceut Sci 3(10): 1597-1606.

25. Azad AK, Mahmud MR, Parvin A, Chakrabortty A, Akter F, et al. (2014) Ethnomedicinal surveys in two Mouzas of Kurigram district, Bangladesh. World J Pharm Pharmaceut Sci 3(10): 1607-1620.

26. Kamal Z, Bairage JJ, Moniruzzaman, Das PR, Islam MT, et al. (2014) Ethnomedicinal practices of a folk medicinal practitioner in Pabna district, Bangladesh. World J Pharm Pharmaceut Sci 3(12): 73-85.

27. Anzumi H, Rahman S, Islam MA, Rahmatullah M (2014) Uncommon medicinal plant formulations used by a folk medicinal practitioner in Naogaon district, Bangladesh. World J Pharm Pharmaceut Sci 3(12): 176-188.

28. Esha RT, Chowdhury MR, Adhikary S, Haque KMA, Acharjee M, et al. (2012) Medicinal plants used by tribal medicinal practitioners of three clans of the Chakma tribe residing in Rangamati district, Bangladesh. Am Eur J Sustain Agric 6(2): 74-84.

29. Malek I, Miah MR, Khan MF, Awal RBF, Nahar N, et al. (2014) Medicinal plants of two practitioners in two Marma tribal communities of Khagrachhari district, Bangladesh. Am Eur J Sustain Agric 8(5): 78-85.

30. Shakera J, Mandal R, Akter T, Nahar N, Rahmatullah M (2019) Folk medicine in Bangladesh: Healing with plants by a practitioner in Kushtia district. Arch Pharm Pharmacol Res 1(5).

31. Rahmatullah M, Jannat K, Nahar N, Al-Mahamud R, Jahan R, et al. (2019) Tribal medicinal plants: documentation of medicinal plants used by a Mogh tribal healer in Bandarban district, Bangladesh. Arch Pharm Pharmacol Res 1(5). 
32. Shova NA, Islam M, Rahmatullah M (2019) Phytotherapeutic practices of a female folk medicinal practitioner in Cumilla district, Bangladesh. J Med Plants Stud 7(4): 1-5.

33. Jannat K, Al Mahamud R, Jahan R, Hamid A, Rahmatullah M (2019) Phyto and zootherapeutic practices of a Marma tribal healer in Bandarban district, Bangladesh. Int J Appl Res Med Plants 2(1): 9.

34. Shandhi MM, Khatun T, Mondol N, Patwary SA, Jannat K, et al. (2019) Tying or hanging of plants to body to cure diseases: an esoteric method of treatment. J Med Plants Stud 7(2): 131-133.

35. Mondol N, Patwary SA, Shandhi MM, Khatun T, Jannat K, et al. (2019) A study of folk medicinal practices in Debashur village, Gopalganj district, Bangladesh. World J Pharm Res 8(5): 589-598.

36. Jannat K, Shova NA, Islam MMM, Jahan R, Rahmatullah M (2019) Herbal formulations for jaundice treatment in Jamalpur district, Bangladesh. J Med Plants Stud 7(2): 99-102.

37. Hosen MS, Rahmatullah M (2019) Simple phytotherapeutic practices of a Tripura tribal medicinal practitioner in Bandarban district, Bangladesh. J Med Plants Stud 7(1): 93-95.

38. Hossain U, Rahman MO (2018) Ethnobotanical uses and informant consensus factor of medicinal plants in Barisal district, Bangladesh. Bangladesh J Plant Taxon 25(2): 241-255.

39. Rahmatullah M, Nuruzzaman M, Hossan MS, Khatun MA, Rahman MM, et al. (2010) An ethnomedicinal survey of folk medicinal practitioners of Shitol Para village, Jhalokati district, Bangladesh. Adv Nat Appl Sci 4(4): 85-92.

40. Balberona AN, Noveno JJ, Angeles MGB, Santos RI, Cachin EJDJ, et al (2018) Ethnomedicinal plants used by the Ilongot-Egongot community of Bayanihan, Maria Aurora, Aurora, Philippines. Int J Agric Technol 14(2): 145-159.

41. Rashid MM, Rafique FB, Debnath N, Rahman A, Zerin SZ, et al. (2012) Medicinal plants and formulations of a community of the Tonchongya tribe in Bandarban district of Bangladesh. Am.-Eur J Sustain Agric 6(4): 292-298.

42. Sihotang VBL (2011) Ethnomedicinal study of the Sundanese people at the Bodogol area, Gede Pangrango Mountain National Park, West Java. Garden's Bulletin Singapore 63(1,2): 519-526.
43. Majumdar K, Datta BK (2007) A study on ethnomedicinal usage of plants among the folklore herbalists and Tripuri medical practitioners: Part-II. Nat Prod Radiance 6(1): 66-73.

44. Khan MA, Islam MK, Siraj MA, Saha S, Barman AK, et al. (2015) Ethnomedicinal survey of various communities residing in Garo Hills of Durgapur, Bangladesh. J Ethnobiol Ethnomed 11: 44.

45. Blasco FA, De Guzman GQ Alejandro GJD (2014) A survey of ethnomedicinal plants in Surigao Del Sur Mountain Range, Philippines. Int J Pure App Biosci 2(4): 166-172.

46. Datta B, Rupaly PA, Biswas D, Hossain MS, Begum F, et al. (2015) Tribal medicinal practices in Bangladesh - a case study of a Tonchongya healer in Cox's Bazar district. J Chem Pharm Res 7(5): 1288-1292.

47. Ningombam DS, Devi SP, Singh PK, Pinokiyo A, Thongam B (2014) Documentation and assessment on knowledge of ethno-medicinal practitioners: A case study on local Meetei healers of Manipur. IOSR J Pharm Biol Sci 9(1): 53-70.

48. Rahmatullah M, Mou MR, Lodh D, Bappy MS, Irin S, et al. (2017) Some medicinal plants of the Rema-Kalenga Wildlife Sanctuary in Habiganj district Bangladesh. J Med Plants Stud 5(2): 180-182.

49. Choudhury S, Sharma P, Choudhury MD, Sharma GD (2012) Ethnomedicinal plants used by Chorei tribes of Southern Assam, North Eastern India. Asian Pac J Trop Dis 2(1): S141-S147.

50. Silalahi M, Supriatna J, Walujo EB, Nisyawati (2015) Local knowledge of medicinal plants in sub-ethnic Batak Simalungun of North Sumatra, Indonesia. Biodiversitas 16(1): 44-54.

51. Rufatto LC, Gower A, Schwambach J, Moura S (2012) Genus Mikania: chemical composition and phytotherapeutical activity. Rev Bras Pharmacogn 22(6): 1384-1403.

52. Chowdhury JU, Nandi NC, Yusuf M (2007) Aromatic plants of Bangladesh: constituents of the leaves and flowers oils of Mikania cordata (Burm.f.) Rob. Indian Perfumer 51: 56-59.

53. Oliveira FdeA, Andrade LN, de Sousa ÉBV, de Sousa DP (2014) Anti-ulcer activity of essential oil constituents. Molecules 19(5): 5717-5747. 